\title{
Sønderjylland 1926.
}

\section{Af Thade Petersen.}

\section{Grænsen.}

Fær d s ele n over Grænsen lettedes væsentligt, idet Vịsumtvangen ophørte den $\left.20 / 5(\mathrm{H} .5 / 5)^{*}\right)$, og det gjordes lettere for Biler at komme over $\left(\mathrm{H}^{11}{ }^{11} \mathrm{~s}\right)$. De sekundære Overgangssteder, der var spærret paa Grund af Mundog Klovesyge, aabnedes nu ogsaa (H. $\left.{ }^{24} / 8\right)$. Iøvrigt har Bevogtningen fra dansk Side varet meget lempelig. Ved Kollund passeredes Grænsen sydfra af 100,000 i et Aar; af dem blev kun 6 tilbagevist. Af en halv Million paa hele Strækningen kun 60-70. (Av. ${ }^{14} / 8$ ). Alligevel klagede en Del Tyskere med liden Ret over Bevogtningen i Anledning af formentlig forsinket Behandling af et Andragende om Fællespas (H. $\left.{ }^{21} / \mathrm{o}\right)$.

Fra tysk Side tales der $i$ visse Kredse stadig om Grænsedragningens Uretfærdighed. Ved Afsløringen af en Mindesten i Flensborg for de faldne af Reg. Nr. 86 udtalte Oberst Ahlefeld Haabet om, at "med Skændselsdiktatet fra Versailles ogsaa den under franske Bajonetter tilvejebragte Voldsgrænse maa bryde sammen«, (H. ${ }^{15} / \mathrm{a}$ ), og Fru Jane Voigt fik paa det tyske Folkepartis sendemandsmøde i Neumünster vedtaget en Udtalelse om, at Partiet wikke anerkender Grænsens Retmæssighed men kræver en Revision" (H. " $/ 11$ ).

Lige over for dem og lignende staar dog andre, der giver Udtryk for Tilfredshed med Grænsedragningen. Johan Lunding i Reinfeld, en Hjemmetysker fra Haderslevegnen, skriver saaledes i "Vossische Zeitung", at Gransen mod Nord wer draget tilnærmelsesvis rigtigt«. (H. ${ }^{16} / 3$ ). Og ved et Fredsmøde paa Dybbøl sagde Lærer Duus fra Altona: "Vi har lært og erfaret, at Bismarcks Jern- og Blodpolitik ikke var noget, der kunde bygges

$\mathrm{H}=$ Hejmdal, Av. = Flensborg Avis, $\mathrm{L}=$ Nordslesvigsk Landbrugs- og Mejeritidende, $\mathrm{Gr}=$ Grænsevagten. 
pas«. (H. ${ }^{2} / 8$ ). Betydningsfulde Udtalelser om Grænsens Rigtighed og Fasthed fremkom især fra de nordiske Parlamentarikere under deres Besag paa Dybbol og andre Steder i Nordslesvig. Professor Weibull fra Lund sagde ved denne Lejlighed, at Tyskerne bør vide, at der staar et enigt Norden bag denne Grænse. (H. ${ }^{17} / k$ ). Ved denne og andre Lejligheder har Tyskerne imidlertid sogt at paadutte Danmark Græn seflytning bestræbelser. Ved et tysk Historikermode i Kiel paastod Regeringspræsident Johannsen saaledes, at Danmark endnu driver Ejderpolitik, hvilket blev gendrevet af »Schl.-H. Landesztg." (H. ${ }^{20} / 4$ ). Paa samme Linje ligger en Erklæring fra "Schl.-H. Bund" om, at Parlamentarikerbesnget maa anses som en Udfordring, (H. $\left.{ }^{25} / \mathrm{s}\right)$ og en Paastand af Pastor Schmidt i Folketinget om, at $H$. P. Hanssen i sin Tid havde leget med Dannevirkegrænsen. (H. $\left.{ }^{25} / 10\right)$. Denne Paastand blev hvast vist tilbage af Hanssen, og Schl.-H. Bunds Erklæring viste sig senere at være udstedt af nogle Medlemmer uden Mandat. (H. ${ }^{25} / 8$ ). Et vigtigt Indlæg i Grænsedebatten var Tardieus Bog "Slesvig paa Fredskonferencen", der dog viste sig at indeholde ffere Urigtigheder. (H. ${ }_{22}^{2}$ S. Aarb. 26 S. 161-204).

Mere end alle Udtalelser om Grænsen betyder dog den Kendsgerning, at der $\%$ undertegnedes en Voldgif tst raktat mellem Danmark og Tyskland, som omfatter alle Tvistigheder, der maatte opstaa. Den gælder i 10 Aar og fortsættes derfter i 5-aarige Perioder, naar den ikke opsiges. (H. $3 / 6$ ). "Hamb. Fremdenbl." siger om den, at dens politiske Betydning maa vurderes hojere end den mellem Sverrig og Tyskland. (H. ${ }^{17} / 6$ ).

Det vigtigste Grænsesporgsmaal, M indretalle t s R e t, naaede omsider ogsaa paa tysk Side et Skridt frem. Kort efter Nytaar talte Overpræsident Kürbis ved Aabningen af Provinslanddagen om, at en Mindretalsordning snart vilde blive givet. Han onskede, at Mindretallet maatte faa den Frihed til Udvikling af sine aandelige Interesser, der tilkom det i Samklang med Historien og Udviklingen af Frihedstanken for Grænsebefolkningen. (H. $8 / 1$ ). Det lad jo godt. Der kom ogsaa snart en officiel Erklæring om, at Mindretalsordningen snart kunde ventes, men den var dog endnu kun under Forberedelse. (H. ${ }^{13 / 1}$ ). $\mathrm{Nu}$ krævede den slesvigske Forening imidlertid en snarlig 
Lasning (H. $\left.{ }^{18} / 1\right)$, og dansk Skoleforening i Flensborg bad Ministeren om at fremskynde Sagen og bl. a. give Forældrene frit Valg af Skole og give danske Kilasser i Landsbyer, hvor et betydeligt Antal krævede det. (Av. ${ }^{10 / 1}$, H. ${ }^{10} / 1$ ). Paa den anden Side lykkedes det Tyskerne at faa Ministerpræsidenten til at love, at han vilde forhandle med de slesv.-holst. Landdagsmand, før Afgørelsen blev truffen. (H. ${ }^{14} / 1$ ). Endelig ${ }^{13} / 2$ of entliggjordes Ordningen, der dog stod langt tilbage for den danske, bl. a. derved, at den trak snævre Grænser for Indretningen af danske Skoler. (H. ${ }^{15} / 2$ Av. ${ }^{14} / 2$, Gr. S. 41-57, 70-78, 101-107). Overpræsidenten lovede imidlertid, at den skulde blive gennemfort loyalt (H. ${ }^{3}$ og $/ 3$ ), og Kultusminister Becher sagde, at den var vedtaget enstemmigt. (H. $8 / 3$ ).

Skønt den sent givne Mindretalsordning saaledes var meget tarvelig, gjordes der fra tysk Side stærk Indsigelse mod den. Halvdelen af det oploste Timandsudvalg af Provinsudvalget paastod, at offentlige Skoler med dansk Undervisningssprog var en Fare for Tyskheden $\left(\mathrm{H}^{11} / \mathbf{1}\right)$ og søgte at hindre Ordningens Fremkomst. (H. $\left.{ }^{15} / 1\right)$. Schl.H. Bund i Flensborg hævdede, at Sl.-H. Krav ved den Maade, Ordningen var meddelt paa, var sblottet som egenkærligt og gjort til Spot for Udlandet" (H. ${ }^{11 / 3}$ ) og paa et Protestmøde i Neumünster udtalte det, at den var »i Modstrid med det tyske Mindretals Vilje og førte til, at dets nationale Interesser led Skade". Bestyrelse og Tilsynsraad nedlagde derpaa deres Mandater. (H. ${ }^{12} / 3$ ). Se videre under $2 \mathrm{c}$.

Ogsaa Nord fra fik Utilfredsheden Næring, idet Pastor Schmidt sagde, at Ordningen hverken tilfredsstillede Schl.-H. eller de tyske Nordslesvigere. Han taler stadig om kulturel Autonomi. (H. ${ }^{9 / 3}$ ).

\section{Nationalt Liv ved Grænsen.}

a) Dansk Syd for Grænsen.

Var de Rettigheder, den tyske Mindretalsordning gav Danskerne, end kun smaa, saa tog de straks fat paa at udnytte dem. Allerede $7 / 3$ meddelte Fl. Av., at der snarest muligt vilde blive aabnet en offentlig dansk Skole i Harreslev. (Av. $7 / 3$, H. ${ }^{13} / 4$ ). Den begyndte ${ }^{16} / \mathrm{s}$ med 28 
Born (Gr. S. 187). I Begyndelsen af Juni fulgte den i Jaruplund. (H. $3 / 6$, Av. ${ }^{3} / 6$ ). En Privatskole aabnedes ${ }^{5} / 5$ i Store Tarup (H. ${ }^{6} / \mathrm{s}, \mathrm{Av} .{ }^{6 / 5}$ ) og en lignende ved Kobbermullen. (Av. ${ }^{13} / \mathrm{s}$ ). Der blev imidlertid hurtig Grund til at klage over Udforelsen af Forordningen. (H. 15/5). Sønderjydsk Skoleforening bevilgede Understottelse til 68 Elever fra Sydslesvig, deraf Halvdelen fra Flensborg By, til Vinterkursus paa danske Høj-, Efter- og Fagskoler. (Av. ${ }^{18}{ }_{/ \mathbf{a}}$ ).

Den danske Menighed i Flensborg fik ${ }^{17} / 1$ en ny Andenprast, H. F. Petersen. (Av. ${ }^{10} / 1$ ). Der konfirmeredes 100) Born i "Ansgar". (Av. ${ }^{23} / 3$ ). Menigheden fik fra $1 / 5$ Helligaandskirken til Leje indtil 1936 for $400 \mathrm{Mk}$. aarlig. (Av. ${ }^{14} / 3,{ }^{28} / 4, H .{ }^{15} / 3$.) Istandsæettelsen af den regnedes at ville koste 50,000$)$ Mk. (Av. ${ }^{22} / \mathrm{p}$ ). I Bidrag til den var der $\mathrm{i}$ November indkommet 13.3(2) Kr. og $54,872 \mathrm{Mk}$. (Av. ${ }^{10 / 11}$ ).

Skovrider Piper i Hareskov testamenterede 50,000 Kr. til dansk Kirke og 100,000 til dansk Skole i Flensborg. (H. ${ }^{13} / 1$ ).

Her skal ogsaa nævnes, at Provinssynoden med 46 Stemmer mod 41 afslaar Flytning af Bispesadet til Slesvig. $\left(\mathrm{H} .{ }^{3} / \mathrm{o}\right)$.

Made- og Foreningsliv skad ogsaa dette Aar nye Skud og trivedes godt. I Januar aabnedes en Burnelæsestue i Flensborghus. (Av. ${ }^{10} / 1$ ). I Valsbol holdtes et godt besngt Landbrugskursus. (Av, ${ }^{3 / 2}$ ). En Ungdomsuge holdtes i Valsbol, Jaruplund, Tarup, Harreslev, Hyrup, Flensborg, Lyksborg, Slesvig og Agtrup. (Av. ${ }^{23} / 2,2 / 3$ ). Antallet af udlaante Bøger fra Bogsamlingen i Flensborg viste nogen Tilbagegang (3345). Derimod havde Larsesalen haft 1:61 hyppigere Besag og Barnebiblioteket 938 Fremgang i Udlaan. (Av. ${ }^{21} / 4$ ). Aarsmødet i Flensborg $8 / 6$ talte 4100. Red. Christiansen opgjorde Aktiver og Passiver i Arbejdet. (Av. ${ }^{8 / 6}$, H. ${ }^{7 / 8}$ ). Paa Teatret i Flensborg gaves der ${ }^{30} / 1$ første Gang siden Begyndelsen af Firserne offentlig dansk Forestilling (Erasmus Montanus) (Av. ${ }^{2} / \mathrm{a}$, H. $1 / 2$, . Og i November sang det store Kor fra Haderslev i Flensborg Hus. (Av. $1 / 11$ ).

I Stedet for "Flensburger Volksbank" sogtes en ny dansk Bank oprettet i Flensborg, som det lykkedes at faa dannet et godt Grundlag for $\left(250,000 \mathrm{Mk}\right.$.) H. ${ }^{2}$, Av. $\left.{ }^{31} / 7\right)$.

I November vedtog Flensborg Byraad enstemmig et 
dansk Forslag om Nedsættelse af et Udvalg til E r hvervslivets Fremme i Byen. (Av. ${ }^{20} / 11$ ).

Advokat Ravn i Flensborg blev omsider genindsat i sin Bestilling som Notar. (Av. ${ }^{10} / 11$ ). Derimod forefaldt der i samme By et grimt Udslag af gammel tysk Ufordragelighed, idet en Krigsinvalid, der havde "Tjenestemandsattest", afvistes, fordi han var Medlem af den slesvigske Forening. (H. ${ }^{30} / 7$, Av. ${ }^{30} / 7$ ). Efter en Maaneds Tids Forløb maatte man dog give ham Forsørgelsesbevis. (H. ${ }^{23} / 8$ ). Imens havde baade Overborgmester Todsen og Landraad Wallroth udtalt, at efter deres Mening kunde Dansksindede godt være Embedsmænd, og var det ogsaa. (Av. ${ }^{10} / \mathbf{s}$ ).

b) Tysk Syd for Grænsen.

I en Artikel hævder Ernst Schröder, at det ikke nu, som før Krigen, er Staten men Grænsebefolkningen, der har Ledelsen i G ræn se k a mpen. (H. ${ }^{12} / \mathbf{s}$ ). Imidlertid er Tyskerne ivrige nok for at faa Staten til.Hjælp. I det preussiske Statsraad stillede den borgerlige Gruppe og Socialdemokraterne Forslag om at anmode Regeringen om at sætte tilstrækkelige Midler paa Budgettet 1927 til planmæssig og omfattende Fremme af grænsepolitisk Tarv i Slesvig-Holsten. (H. ${ }^{10} / 11$ ). Nogle onskede endog en Bane tværs over Landet fra Bredsted til Kappel, fordi de haabede derved at "rejse et Dige mod den stadig længere fremtrængende Danskhed ". (Av. 4/ø).

Af 125 tyske Biblioteker i Slesvig findes de 63 i Flensborg Landkreds og 54 i Sydtonder Kreds, altsaa op mod Grænsen. (H. $7 / \%$ ). Til et tysk Forsamlingshus i Flensborg samles der ind hos tyske Kommuner. (H. ${ }^{28} / 7$ ).

Schleswig-Holsteiner-Bund, der er den vigtigste Organisation af tysk Grænseinteresse, fik i Oktober en ny Bestyrelse med Professor Scheel som Formand. (H. ${ }^{28} / \mathbf{1 0}$ ). Den gamle havde nedlagt sit Mandat som Protest mod Mindretalsordningen. (Se under 1). Dette Bestyrelsesskifte betød Plads for noget større Forsonlighed. Prof. Scheel siger: "Vi maa have Agtelse for den fremmede Nationalitet«. (H. ${ }^{27} / 10$ ). Udslag af vildt Had forekommer dog stadig. Bl. a. brændte nogle Tyskere i Aventoft et Dannebrog. (Av. ${ }^{17} / 3$, H. ${ }^{3 / 4}$ ).

Utiltalende Forhold fra Afstemningstiden afslorede Wall i Obdrup $i$ en lille Pjece. $\left(\right.$ H. $\left.^{23}{ }^{30} / 3\right)$. Han 
klager senere til Justitsministeren over, at Skotcjshandler Jørgen Petersen i København har snydt ham. (H. ${ }^{27} /{ }^{10}$ ).

c) Tysk i Nordslesvig.

ved Folketingsvalget ${ }^{2} / 12$ havde Tyskerne en Fremg a n g af $15,6 \%$. (H. $\% / 12$ ).

Flere store tyske Gaardejere paa Als skal have tilbudt Jordlovsudvalget deres $\mathrm{G}$ a a $\mathrm{r}$ d e til urimelige Priser. Der blev ikke taget Hensyn til dem. (H. ${ }^{10} / \mathrm{s}$ ).

Der oprettedes i September en tysk Hypotekb a n k i Haderslev med 45,000 Kr. Aktiekapital for at hjælpe Tyskere. Vogelgesang er Direktør. (H. $\left.{ }^{11} / \mathrm{a}\right)$. Aktiekapitalen forhøjedes dog snart til 450,000, og det viste sig. at V. indforte Forkøbsret paa Ejendommene. (H. $3 / 11$ ).

Behandlingen af Tyskerne er naturligvis fortsat i det menneskelige, retfærdige Spor, den fra først af slog ind paa. Den amerikanske Professor Knight roser da ogsaa den danske Mindretalsordning som et Mønster for andre. (H. ${ }^{20} / \mathrm{s}$ ). Og selv en Tysker, Frkf. Ztgs. Korrespondent i København, maa anerkende, at de danske Love baade i Indhold og Haandhævelse viser Menneskekærlighed og Billighed overfor Mindretallet. (H. $\left.{ }^{22} / 1\right)$.

Tyskerne taler stadig om kulturel Autonomi som deres Ønskers Maal. Paa et Møde i Toftlund viste $H$. P. Hanssen imidlertid, hvor lidet anvendelig den var her. (H. ${ }^{23} / 2$ ). Pastor schmidt, der særlig er Talsmand for den, gaar uden om Spørgsmaalet. (H. ${ }^{27} / 2, \% / 3$ ). Imidlertid opgiver "Apenr. Tagebl.« den (H. ${ }^{2}{ }^{\prime}$ ), og paa Kvindeligaens Konference $i$ Flensborg sagde en Taler fra Esthland, at den ikke var at anbefale, da den satte Skel mellem Folkedelene. (H. ${ }^{27} / \mathrm{s}$ ).

Trods god Behandling giver Tyskernes Ut ilfredshed sig undertiden saa utiltalende Former som den bekendte Nogleaffære i Højer, der indbragte Byraadet en Tilrettevisning fra Ministeriet. (H. ${ }^{31} / 7$ ). Sammesteds var de tyske Medlemmer traadt ud af Skolekommissionen, fordi de ikke kunde faa deres Vilje i et bestemt Punkt. De maatte efter Opfordring af Ministeren træde ind igen, fordi et saadant Hverv ikke kan nedlægges. (H. $7 / \%$ ).

I kirkelig Henseende har Tyskerne arbejdet. videre paa Udviklingen af de Fremmedmenigheder (den sl.-holst. Landskirke i Udlandet) som almindeligt kaldes 
Frimenigheder. Et Udvalg skaffede dem i faa Maaneder $30,(0) 0 \mathrm{Mk}$. Syd fra. (H. 1/5). ${ }^{20} /$ afleste Pastor Petersen fra Læk Gottfriedsen som Præst i Tinglev. (H. ${ }^{24} / 8$ ). Og $5 / 12$ blev Pastor Horstmann fra Marne indsat som Præst for Tyskerne i Sdr. Vilstrup. (H. $7 / 12$ ). Her vilde de gere Krav paa at bruge Kirken uden Vederlag, men Stiftsøvigheden foreslog en Ordning, hvorefter de skulde betale $500 \mathrm{kr}$. for Brug af den 15 Gange aarlig. (H. ${ }^{24} / 8$ ). Endnu mere fordringsfuldt var deres Andragende om Ret for deres Præster til at forrette Vielser med borgerlig Gyldighed. Det blev afslaaet. (H. $\left.{ }^{21} / 7\right)$.

Paa Sk ole $\mathrm{n}$ S Omraade har Tyskerne virket ivrigt for Oprettelsen af Privatskoler. En saadan blev bygget i Aabenraa og indviet ${ }^{20} / 10$. $\left\{\right.$ H. ${ }^{27} / 10$ ). Den ventede 170-180 Elever. (H. ${ }^{12} / 1$ ). Ved Aarets Begyndelse fandtes der 11 saadanne Privatskoler i Nordslesvig. (H. \%/2). Flere Steder tog de imidlertid Livet af de tysksprogede Kommuneskoler. Saaledes i Nørborg og Graasten. (H. ${ }^{19} / 2$ ). I Tinglev kom det til stærk Spanding vedrorende Realskolen, hvor en Del Tyskere krævede særlig tysk Undervisning. (H. ${ }^{30} / 1,4 / 2, \mathrm{Av} .{ }^{30} / 1$ ). Da der ikke kunde opnaas Enighed (H. $\left.{ }^{11} / 2\right)$, nargtede Sogneraadet Tilskud til den tyske Skole. (H. ${ }^{12} / 2$ ). I Sønderborg krævede de en tysk Realklasse med tysk Undervsining og fuld Eksamensret. (H. ${ }^{10} / \mathrm{s}$ ).

De fleste tyske Børn gaar dog i de ty s sprogede A f delinger af Kommuneskolerne. I Tonder blev der indmeldt 55 i den nye tyske Forsteklasse $\bmod 35$ i 1925. I Haderslev er der 429 i de tyske og 1262 i de danske Aflelinger (H. ${ }^{8 / 2}$ ), et Forhold, der vist vil holde sig længe. (Gr. S. 205). I Aabenraa $610 \mathrm{i}$ de danske, 431 i de tyske mod 570 og 490 i 1920/21. Ved Universitetet i Jena oprettedes der et Aarskursus for Lærere ved saadanne Skoler. (H. $11 / 3,3 / 5$ ). Af Nordslesvigs samlede 24,740 Børn faar 11,13 $\%$ tysk Undervisning. (H. ${ }^{16} / 12$ ).

Af tyske $M ø d e r$ og Foreninger skal kun nævnes, at Knivsbjergfesten havde samlet 5000 . (H. ${ }^{20} / \mathrm{s}$ ). Ved et Mode i Tinglev af tysksindede Studenter i Kobenhavn $14 / 8$ udtaltes der Glæde over, at disse blev her i Landet. (H. ${ }^{18} / \mathrm{s}$ ). De tyske Organisationers Aarsmode i Aabenraa var kun svagt besøgt. Pastor Schmidt sagde her:"Vi staar ikke med fjendtlige Følelser overfor det danske Folk." (H. ${ }^{18} / 8$ ). 
Baade til Kirke og Skole modtager Tyskerne rig Støtte Syd fra. "Jugendspende Nordschleswig" har skænket store Beløb til mange Skoler. Privatskolen i Aabenraa fik alene 75,000 Mk. Den i Tinglev fik fra anden Side 10,000 Mk. (H. ${ }^{12} / 2$, Av. ${ }^{3} / \%$ ).

d) Dansk i Nordslesvig.

Befolkningen er i stadig $\mathrm{V} \propto \mathrm{kst}$ og er nu i Tønder Amt 38,336, (Av. ${ }^{18} / 5$ ) i Sanderborg By 10,271, (H. ${ }^{15} / 12$ ) i Haderslev By 14,096. (H. Amtst. 4/12).

Blandt Myldret af Foreninger og Møder skal kun nævnes, at Grænseforeningen ${ }^{28} / 2-{ }^{14} / \mathrm{s}$ holdt nationale Møder 24 Steder. (Av. ${ }^{28} / 2$ ). Sprogforeningen og Skoleforeningen holdt Efteraarsmade i Slogsherredhus, (Av. ${ }^{21} / 8$ ) og Aarsmode i Rodding ${ }^{27} / 6$. Det overværedes af 1000. Sprogforeningen har nu 2159 Medlemmer (186 Fremgang) den har udsendt 7056 Bøger Nord og 675 Syd for Grænsen. Regnskabet balancerer med 37,672 Kr. Skoleforeningen har 13,025 Medlemmer i Nordslesvig og 3912 i det øvrige Land. (48+129 Fremgang). Til Skolebesøg støttedes 189 fra Nord- og 118 fra Sydslesvig. Regnskabet balancerer med 143,908 Kr. (H. ${ }^{28} / 6$ ).

Nordslesvigsk Kvindeforening har 4156 Medlemmer, Regnskab 23,650 Kr. (H. ${ }^{\circ} / \%$ ).

I et Ungdomsstæyne 'i Tinglev deltog 400 . (H. ${ }^{18} / 7$ ).

Historisk Samfund f. Sønderjylland er vokset med $\mathbf{4 5}$ Medlemmer. (H. $\left.{ }^{30} / \mathrm{s}\right)$.

Haderslev Østeramts Ungdomsforeninger har mistet 324 Medlemmer. (H. Amtst. ${ }^{20} \%$ ).

Sansen for I d r æ t er i god Vækst. Sønderjydsk Idrætsforening har nu 95 Kredse med 3286 aktive og 2174 passive Medlemmer. Antallet er vokset godt det sidste Aar. (H. ${ }^{15} / 3$ ). I September holdt den en stor og vellykket Idrætsfest i Tønder, som talte over 700 Deltagere og mere end 1000 Tilskuere. (Av. ${ }^{14} / 9$, H. ${ }^{13} / 9$ ).

Som sædvanlig holdtes der ogsaa i Aar Afstemnings- og Genforeningsfester rundt om i Landet. (H. ${ }^{16} / 2,10 / 6$, Av. $\left.{ }^{17} / 6\right)$.

Af Besøg skal nævnes Kongeparrets aarlige Besøg, denne Gang i Anledning af Logumkloster Kirkes Genindvielse, $H .{ }^{10^{\prime}} 7$ ) de nordiske Interparlamentarikere paa Dybbøl o. a. St. (H. ${ }^{17} / \mathrm{s}$ ) og de danske og 4 nordiske Bispers 
Besøg i Løgumkloster, Tonder og Randerup Kirker. (Av. ${ }^{11} / 0$ ).

En Begyndelse til stærkere Sam ling af Kræfterne blev gjort, idet Repræsentanter for Skole-, Sprog- og Grænseforeningen drøftede Muligheden af at holde nationale Moder i Fællesskab. Dette enedes man dog om at udsætte foreløbig. (Av. $3 / 2$ ). Ved et Møde i Tinglev $10 / 10$ vedtoges det imidlertid, at Foreningernes Bestyrelser skulde holde et aarligt Fællesmøde om de nationale Opgaver Nord og Syd for Grænsen. (H. $\left.{ }^{18} / 10\right)$.

Som Kuriosum skal anføres, at en Dr. Petersen fra Kiel, Søn af tidligere Provst i Haderslev og Generalsuperintendent i Kiel, Petersen, paa et Universitetsmøde i Flensborg paastod at $J \mathbf{y ~ d s k}$ ikke var Dansk, og at Nordslesvigerne forstod bedre Tysk end Dansk. (Av. ${ }^{22} / 10$ ).

\section{Politik.}

Den politiske Hovedbegivenhed var Folke ting svalget $\% / 12$. Stemmerne faldt ved det saadan, at Venstre fik 21,518, Radikale 3942, Socialdemokraterne 16,506, Konservative 11,307, Tyskerne 10,920, Selvstyrepartiet 2169. Valgte blev Madsen Mygdal, Chr. E. Christensen, C. O. Pedersen, J. P. Nielsen, Ludvig Hansen, Holger Andersen og Pastor Schmidt. (H. 13/12). Da Dr. Karberg efter at være flyttet til Ringkøbing som Amtmand nedlagde sit Mandat som Landstingsmand, traadte Borgmester Fink i hans Sted. (H. $\left.{ }^{27} / 10\right)$. I April nedlagde Redaktør Svensson sin Post som Formand for den konservative Forening i Haderslev. (H. $1 / 5$ ).

Mest har det Røre, der vaktes af Selvstyrepart i et, fyldt i den politiske Drøftelse. Her skal kun nævnes nogle af de vigtigste Punkter.

Corn. Petersen vakte egentlig forst Opsigt, da han fremsatte sin vilde Ide om at belejre Rigsdagen med 800 haandfaste Bonder, forsynet med Madpose og Straasæk (H. $\left.{ }^{13} / 4\right)$, og den konservative Klub i Kobenhavn alligevel hyldede ham og Kylling, mens dog flere fremragende Konservative tog Afstand. (H. $\left.{ }^{21} / 4,11 / 6\right)$. Det viste sig snart, at dette Røre fra forste Færd havde Maskepi med Tyskerne. $\left(\right.$ H. $\left.{ }^{3} / 5,20 / 5,4 / 6\right)$. Tidligt rygtedes det, at Tilhæn- 
gerne maatte ved en Erklæring binde sig til Corn. P. (H. $\left.{ }^{10} / 8\right)$. Det viste sig snart at være en formelig Haandfæstning. (H. ${ }^{10} / \mathrm{s}$ ). C. P. blev nu taget i Forhør. $\left(\right.$ H. ${ }^{23} / \mathrm{s},{ }^{2} / 7$ ). Da C. P. kaldte Statsministeren Forbryder og Roverkaptajn, anlagde Justitsministeren Sag imod ham. (II. ${ }^{28} / 8$ ). Han blev idomt 3 Maaneders Fængsel, (H. ${ }^{30} / 9,2 / 10$ ) der af Landsretten nedsattes til $2000 \mathrm{Kr}$. Bøde. (Av. ${ }^{17 / 10}$ ). Imidlertid havde nogle unge Løjtnanter ladet sig forlede til at hverve Tilhængere blandt aktive officerer. (H. ${ }^{8 / 10}$ ). De blev sat under Tiltale efter Oprørsparagraffen. (H. $5 / 11$ ). Imidlertid truer Gaardejer Sørensen i Kværs med at skyde Sogneraadsformanden. (H. 1/11). Kylling bryder omsider med C. P. (H. ${ }^{20} / 11$ ), og denne, der havde søgt at hænge sig fast ved de Konservative ved Valget, danner tæt for dette sit eget Parti. (H. ${ }^{23} / 11$ ).

\section{Samfundsforhold.}

Indtil Slutningen af 1925 var der ved Udsty kn ing bleven dannet 268 nye Husmandsbrug. (H. ${ }^{3} / 2$ ). Og i Aarets Løb blev der foretaget Udstykning paa Kajnæsgaard. (H. ${ }^{28} / 3$ ) Kehlet, (H. $8 / 2$ ) Nygaard ved Østerlindet, (H. \%) Rønhave og Fiskebæk (H. ${ }^{24} / 3$ ). Flere andre Udstykninger forestaar, bl. a. en Del af Mariegaard i Jels, Rumohrsgaard, Werthemine, (rammelgaard og Grongrøft. Naar den sidstnævnte udstykkes vil der være dannet $100-150$ nye Hjem paa de fordums Herregaardsmarker ved Graasten. (H. $7 / 7$ ). Planen om at danne en Koloni af Thyboer der, blev dog ikke til noget. (H. $\left.{ }^{18} / 8,1 / 6\right)$.

I Tønder Amt bedredes de $\mathrm{h}$ y gie j $\mathrm{n}$ is ke For hold langsomt. (Av. ${ }^{3} / 8$ ). Der døde i 1925308 Mennesker der, af disse 32 af Tuberkulose. I 1926 døde der ifølge Uddrag af Medicinalberetningen for Tønder Amts Lægekreds for 1926 i dette Aar 369, deraf 29 af Tuberkulose. Paa kystsanatoriet ved Augustenborg behandledes der 1925209 Barn. (H. $3 / 8$ ).

\section{Erhverv og Okonomi.}

a) La n d bruget.

Mergelle jet i Københoved skal være det største i Danmark. Siden Krigen er der endnu leveret 750,000 
kbm over Kongeaaen. Det standser nu, da hele Omraadet er forsynet. (H. ${ }^{21} / 9$ ).

Planen for Afvandingen ved Tønder blev ved Nytaar 26 godkendt af Ministeren. (Av. ${ }^{3} / 1$, H. ${ }^{27} / 1$ ). Der toges først fat paa Sejersbæklavningen, hvor der byggedes 11 Broer. (Av. ${ }^{16} / 0$, L. S. 59).

Andre Steder i Tønder Amt arbejdedes der 1925 med 99 Dræningsplaner (569 ha) og 26 Vandlobsreguleringer (1792 ha). (Av. 15/5).

Ved Uddybning og Regulering af Jels Aa afrandes 82 ha $\left(\right.$ H. $\left.{ }^{27} / 4\right)$.

Ved Pamhule kultiveredes en lille Mose. (H. ${ }^{25} / 8$ ).

Paa M a rsken blev det atter et daarligt Aar. Allerede i Januar viste det sig, at Græsland kun vilde give den halve Leje. (Av. ${ }^{15} / 1$ ). Græssernes Tab, der i 1925 kunde anslaas til 2 Millioner, blev i 26 ca. $1 / 2$ Million. (H. ${ }^{30} / 6$, Av. ${ }^{8} / 10$ ).

Plantning af Traer er godt i Gang. Hedeselskabet har i Sonderjylland uddelt Planter for over $53,(100 \mathrm{Kr}$. i 1925. (H. $\% / 2,18 / 7$ ). En Plantningsforening her nede er den storste Aftager af Planter blandt alle Landets $\mathbf{7 1}$ Foreninger. $\left(H .{ }^{15} / \mathrm{e}\right)$.

D i g e b y $\mathrm{g}$ inge n ved Juvre paa Romo begyndtes i Februar, (H. $1 / 2$ ) men led en Del ved Stormflod i Oktober. (H. ${ }^{12} / 10$, Av. ${ }^{15} / 10$ ) Sydvestdiget derovre blev gjort færdig. (Av. ${ }^{28} / 4,7 / \%$ ). Højer-Emmerlevdiget blev begyndt om Foraaret og gjort færdig i Lobet af Sommeren. (Av. ${ }^{22} / \mathrm{o}$ ).

Forbedringen af Jordfordelingen er skredet godt frem. (H. ${ }^{2} / 11$, L. S. 359).

$\mathrm{H} ø \mathrm{~s}$ t e $\mathrm{n}$ blev til Dels en Skuffelse. Den gav over hele Landet Straa nok. men kun paa de lette Jorder blev Kærneudbyttet over Middelhost. Ogsaa Roerne blev bedst paa let Jord. (H. ${ }^{11 / 9}$ ).

Kvægavisforeningerne med rødt dansk Malkekvag har nu 256 Medlemmer med 2934 Køer, og der er 29 hontrolforeninger, ( 4 flere end i Fjor) $\left(\mathrm{H} .{ }^{27} / 1\right.$ ), der har $86 \%$ af Knerne under Kontrol mod $80 \%$ i Fjor. (L. S. 85). Under Korthornsfallesledelsen staar der 64 Kontrolforeninger med ca. 24,000 Koer i 1577 Besætninger. Baade Mælkemængde, Fedtindhold og Smørmængde er gaat lidt ned fra i Fjor. Det rode Kvags Ydelse staar godt i Forhold til det ovrige Land. Kun paa Fyn og Samsø 
staar det hojere i Smorydelse. I Fedtprocent staar Sunderjylland dog endnu noget tilbage. (H. 8/3, L. 821). Farllesledelsen for Avlen af hollandsk Kvag er gaaet frem med :(4) Køer til 1534. (L. 185). Der er nu $35 \%$ af alle sonderjydske hoer under Kontrol, men der holdes endnu for mange Stude. Tallingen 1925 viste 5000 Fremgang for studene og en lille Tilbagegang for Kiverne. (L. $3(12,5118)$.

To ny Svineslagterier kom i Gang i 1925 og moder nu med de første Beretninger, nemlig Rødding (H. ${ }^{10} / 2$ ) og Vojens (H. ${ }^{1 / 3}$ ). I 1926 kom flere nye i Gang, nemlig Tonder (Av. ${ }^{13}{ }_{3}$ ), Bylderup) (Av. ${ }^{13}{ }_{6}, \mathrm{H} .{ }^{18} / \mathrm{B}$ ) og Aahenraa $\left(H .{ }^{9} / 7\right.$ ). Af de wldre har (xraasten haft 43,527 Svin, og dets Flask blev ved en Bedommelse Nr. 1. (H. ${ }^{20 / 2}$ ). Skærbæk har haft 30,277 Svin og betalt $6 \%$ Udbytte, (H. ${ }^{18} / 3$ ) Sonderborg derimod har arbejdet for dyrt. (H. ${ }^{1 / 3}$ ).

Svineavlen har gjort gode Fremskridt siden Genforeningen. (Av. ${ }^{13} / \mathrm{o}$ ).

II und-og Klovsygen gjorde atter i dette Aar stor Skade. I Juli Maaned blussede den op paa ny over hele Landet. I Tonder Amt kom der i denne Maaned alene 500 nye Besætninger til. (Av. 1/s). I Aabenraa Polikreds anmeldtes der allerede i Juni 8-10 Tilfælde daglig, og 225-30 Besartninger stod under offentligt Tilsyn. (H. 2\%/o). I Haderslev Vesteramt var der derimod i Juli kun 145 Tilfælde i 11 Mejerikredse. (H. ${ }^{10} / \%$ ). Sønderjydsk Mejeriforenings Mund- og Klovsygeforsikring havde et Regnskab paa $1,913,000 \mathrm{Kr}$. (H. ${ }^{13} / 10$ ).

I e jeribruget, der giver Landbruget dets Hovedindtægt, led en Del under Sygdommen. Allerede i 1925 var Mælkemængden steget mindre stærkt end for. Stigningen var $\operatorname{dog} 3 \%=6,691,000 \mathrm{~kg}$ (L. 126). Smøreksportforeningen i Sonderborg solgte 45,360 Dritler Smar (H. ${ }^{22} / 12$ ), og den i Vojens 44,780 (H. Amtst. ${ }^{14}{ }_{1}$ ).

Smorrets Kvalitet, der ved Laboratoriebedommelserne i 19:0) var 0,5 Points under Landsgennemsnittet, naaede i 19250,08 op over det, Haderslev og Sonderborg Amter endog 0,3 og 0,2 over. (L. 299, H. $\% / 1$ ). Haderslev Amt havde sammen med Ribe Amt det højeste Pointsantal for hele Landet. (H. ${ }^{17} / 3$ ). Paa Mejeriudstillingen i Fredericia i 26 var det sønderjydske Smor da ogsaa 0,01 Point over Gen- 
nemsnittet, mens det i 25 var 0,02 under. (H. 12/4, L. 251). i5 \% af de sønderjydske Mejerier afregner nu efter Fedtenheder, for hele Landet kun $20 \%$. (H. ${ }^{\mathbf{1 7}} / 3$, L. 93). $81 \%$ af Mejerierne er her Medlem af en Mælkebedømmelsesforening, i hele Landet $32 \%$ af dem, der indsender Oplysninger til Mejeridriftsstatistikken. Mælkeforbruget til et Pund Smør er for stort hernede. (L. 460). Bestyrelsen for Sinderjydsk Mejeriforening, der omfatter 125 Mejerier, fremsatte mod Aarets Slutning et Forslag til Kralitetsbetaling for Mælken. Der skulde kunne gives Tillæg indtil 0,02 Øre Pundet og fradrages indtil 0,09 Øre. (L. 764). At der er Mælkebedømmelse ved $90 \%$ af sønderj. Mejerier, har paaviselig forbedret Ssørrets Kvalitet. (H. ${ }^{10} / 12,18 / 12$ ). Der er i Sonderjylland endnu kun 1 eller 2 Mejerier i hvert Amt uden Koleanlæg. (L. 218). Siden 1920 er 25 af Mejerierne ombygget, sidst det i Rødekro. (H. ${ }^{31} / 2,1 / 2$ ).

Landbrugets Rentabilitet var daarlig i 25/26. Paa 50 Gaarde i Aabenraa Amt blev Nettoudbyttet $\div 26$ Kr. pr. ha. (H. ${ }^{10} / 11$, Landbrugsregnskaber fra Aabenraa Amts Regnskabsforening 1925/26.)

Faglig oplysning soges godt. Graasten Landbrugsskole er starkt besugt. (H. $\left.{ }^{13 / 7},{ }^{10} / 10\right)$.

I Sanderborg Amt solgtes der 1924 paa Landet 334 Ejendomme for 6,566,060 Kr., i Haderslev Amt 765 for $15,167,000$.

b) Industriog $\mathrm{Haand}$ a $æ$ rk.

Hajspandingsværket kobte Osterlindet Elektricitetsværk. (H. $\left.{ }^{11} / 1\right)$. Dets Regnskab balancerer for 1925 med 845,672 Kr., dets Status med 5,327,001), dets Stilling er god. (H. \%). Haderslev Byraad anlagger Sag mod det, fordi det ikke mere aftager Strøm fra Haderslev. (H. $5 / 2$ ). Danskengelsk Benzin- og Petroleumskompagni vil opfore et stort Tankanlæg til 180,000 l ved Tonder. (Av. ${ }^{15} / 12$ ). Ved Beslagskolen paa Graasten Landbrugsskole, den eneste udenfor Landbohøjskolen, aflagde det forste Hold Elever Prøve og bestod den meget godt. (H. ${ }^{29} / \mathbf{6}$ ).

c) Handelog Skibsfart.

Paa et Købmandsmosde i Haderslev vedtoges en fornyet Henvandelse til Rigsdagen om Ændring af Lovbestemmel- 
serne om retslig Inkassation af mindre Beløb og om Nedsættelse af Fragt-, Telegraf--, Telefon- og Portotaksterne samt en Henstilling til Banker og Sparekasser om at nedsætte Rentefoden. (H. $\left.{ }^{15} / \mathbf{6}\right)$.

For $\mathbf{T}$ m merhandele $\mathrm{n}$ var Aaret ikke godt. Cimbria havde $44,789 \mathrm{Kr}$. Underskud $\left(\mathrm{H} .{ }^{28} / 3\right)$ og Hansborg maatte afskrive 34,000 som Tab. Det havde $416,000 \mathrm{Kr}$. ()msætning og et Lager til 169,000. (H. Amtst. ${ }^{10} / 3$ ). De likviderende samvirkende Brugsforningers Forhold blev endelig ordnet saadan, at Kreditorerne faar deres Tilgodehavende, $190,000 \mathrm{Kr}$. (H. $3 / 7$ ).

I de større sønderjydske Havne undkom der i 1925 folgende Antal Skibe: i Haderslev 2270, Aabenraa 1381, Sonderborg 3884, Egernsund 2111 med tilsammen 336 Mill. kg Ladning, mens de udforte 214 Mill. kg. (H. ${ }^{22} / 2$ ). Januar Kvartal 26 viser lidt Opgang for Haderslev og Sanderborg. (H. ${ }^{8 /-1}$. Graasten Havn havde 1923- ${ }^{31}$ is $2553 \%: 2 \mathrm{Kr}$. ()verskud. ( $H$. $s / 0$ ). Uddybningen af Højer Dyb var omtrent færdig i Juli. (Av. ${ }^{1 *} / 7$ ). Fra Haderslev sattes en noget storre Damper i Gang til Stykgodsfart. (H. ${ }^{16} / 1$ ).

Stor Kullerfangs t i Lillebælt forte 100 fremmede Baade til Sinderborg. (H. $\left.{ }^{28} / 1,, \% / 2\right)$. De vil dog næppe holdle sig der længe. (H. $\left.{ }^{16} / 4\right)$.

\section{d) Pengeforhold.}

Pengeknapheden var stor, til Trods for den Kapital, der er bleven tilfurt Landet (H. 1/e), men dog ikke saa stor som Tyskerne undertiden vil give det Udseende af. Nettoformuen var $1 / 425810$ Mill. (H. ${ }^{30} / 10$ ). Til Trods for Knapheden skete Afbetalingerne dog lige sikkert om end langsommere. (H. ${ }^{28} / 6$ ). En god Hjælp var det, da Staten efter Realkreditkommissionens Forslag viste sig villig til at stille 20 Millioner til Raadighed for Sparekasserne. (H. ${ }^{4} / 3,23 / 3$ ). Foreløbig blev det 10 Mill. (H. $4 / 3,14 / 5$ ) Der hlev i furste Omgang endda kun Brug for 8 Mill. (H. ${ }^{15 / 7}$ ), som straks bevilgedes. (H. ${ }^{19} / \mathrm{s}$ ).

Landboforeningerne onskede Driftsla an efore $\mathbf{n}$ i $\mathbf{n}$ e $\mathbf{r}$ oprettet. (H. $1 / 11$ ). En saadan, der fandtes i Tingler, ansaas ikke for at arbejlle efter Lovens Forudsatninger. (H. ${ }^{15} / \mathrm{s}$ ).

Sonderjyllands threditforening har i $25 / 26$ udlaant $10,144,500$ Kr. $\left(\right.$ H. $\left.{ }^{13} / 10\right)$. Statsgarantien for dens 3 . 
Serie har gjort, at dens Kurser er steget starkt. (H. ${ }^{30}{ }_{101}{ }_{10}$. Den foresiaar en $5 \%$ Serie med Statsgaranti, en sunderjydsk Hypotekforening ligeledes og en Omordning af Galden ved $\mathrm{Hjwlp}$ af et Udvalg. (H. ${ }^{18}{ }_{12}$ ).

B a n k r n e havde trods alt tjent godt. Haderslev Bank gav $8 \%$ Ldbytte or havde 393 Mill. Omsatning. (II. $\left.{ }^{22} / 2,{ }^{20} / 2\right)$. Graasten B. $8 \%$, (H. $\left.{ }^{23} / 2\right)$. Folkehanken for Als og Sundeved $8 \%$. (H. ${ }^{12 / 3}$ ). Nordslesvigsk Folkebank giver 80,000 i Ldbytte. (H. $\left.{ }^{15 / 3}\right)$. Skarbak Bank 5\% \%. (H. $\left.{ }^{20}{ }_{3}\right)$. Rodding Bank har haft 36,391 i Overskud. (H. ${ }^{22} / 3$ ). Derimod var Tonder Landmandsbank kommen i Vanskeligheder og maatte have en Praferenceaktiekapital paa $30,0.000$ tegnet (Av. ${ }^{23 / 3},{ }^{31 / 3}$ ) og afskrive 523,0,54 (Av. ${ }^{18} / 3$ ). Ligeledes matte Nordslesvigsk Bank standse og likvidere med 200,000 Underskud. (H. $\left.{ }^{23} / 3,3 / 4\right)$. Folkebanken for Als og Sundeved tog en ny Bygning i Brug. (H. ${ }^{22} / 2$ ).

Rentenedsæt te lse krævedes starkt, (H. ${ }^{12}{ }_{5}$ ) og sattes i $\Gamma$ ærk i Sonderborg Amt fra 1/4. (H. $\left.{ }^{29} / 1\right)$. Sparekasserne nedsatte den, men Bankerne syntes ikke villig til det. (H. $\left.{ }^{1 / 2}\right)$.

Slesvigske Bonders H y ot ek kas e blev ophæret, da den ikke kunde faa Stempelbegunstigelse. (H. ${ }^{21 / 5}$ ). Der sogtes saa oprettet en $H y$ p ot $\mathrm{k}_{\mathrm{b}} \mathrm{a} \mathbf{n} \mathrm{k}$ ved Laan fra Amerika. (H. ${ }^{24 / 7}$ ). Senere oprettedes en Hypotekkasse i Haab om Statsgaranti for 30-50 Mill. (H. ${ }^{30 / 9},{ }^{7} / 10$ ).

Indskuddene er glædeligvis i Stigning. (H. ${ }^{28}{ }_{10},{ }^{19}{ }_{7}$, ${ }^{15} / 9$, Av. $\left.{ }^{5} / 10\right)$.

I en Valutasag domte danske Domstole efter Grundsatningen Mark er Mark, men tyske ikke. Den tyske Retsopfattelse var andret siden Genforeningen. (H. 13/4 Av ${ }^{15} / 7$ ).

Bestyrelsen for Nordsl. Kreditforening vilde have Jernfondet og Sinderj. Fond til at dakke Underskuddet ved Likvidationen $n g$ fik det for Jernfondets Vedkommende efter Falle Lildholdts Dod. (H. $\left.{ }^{14}{ }^{19} / 1,25 / \mathrm{s}\right)$.

e) $\mathrm{Sa} \mathrm{m} \mathrm{k} \mathrm{e} \mathrm{m.}$

Sma a a nerne kxmpede ogsaa i 1925--26 med store Underskud. I Haderslev Amt havde man ventet, at dette vilde blive $190,010 \mathrm{Kr}$. men i Marts viste det sig at ville blive ca. 250,000 . (H. ${ }^{\theta / 3}$ ). Og selv de paa Als fik et Driftsunderskud af over 19000 Kr. (H. ${ }^{23} / 8$ ). I Aabenraa 
Amt var man allerede for Nytaar 26 klar over, at Smaabanerne maatte standse til 1 . April, og ${ }^{31} / \mathrm{s}$ ksrte det sidste Tog. (H. $3 / 4$ ). Imidlertid havde Staten godtgjort Amterne ${ }^{2}{ }_{3}$ af de Belob, disse havde betalt Preussen for dets Andel i Banerne. (H. 12/1). Allerede i Januar blev Amtsbanegaarden i Aabenraa solgt til et Rutebilselskab, som stod rede til at afløse Banerne $\left(\mathrm{H}{ }^{7} / \mathrm{l}\right)$ ved at siette 5 Rutebiler i Gang. (H. ${ }^{20} / 3$ ). Inden Udgangen af Septemler var alt den nedlagte Banes Materiel solgt for i alt $424,600 \mathrm{Kr}$. (H. $\left.{ }^{27} / \mathrm{s}\right)$.

$\mathrm{St}$ a $\mathrm{t} \mathrm{s}$ b a n e $\mathrm{r}$ e derimod lagde endnu store Planer. Aabenraa Banegaard skulde flyttes (H. ${ }^{15}{ }_{1}, / 3$ ), og Jordarbejdet til en Bro over Alssund begyndtes. (H. ${ }^{29}{ }_{\text {g) }}$.

L a ndevejenes Betydning som Færdselsaarer vokser derimod stadig. I Haderslev Amt var Udbedring og Nybygning siden Genforeningen bleven 391,000 Kr. dyrere end beregnet. (H. ${ }^{2} / 2,15 / 1$ ). En ny Bro over Kongeaaen (ist for Foldingbro planlagges (H. ${ }^{* 1}{ }_{12}$ ), og ved Egernsund suxtes en ny Forge i Gang. (Av. ${ }^{17} 11$, H. ${ }^{21} / 8$ ). Aabenraa $B y$ vedtager at bygge en ny Kystvej ud mod Syd. (H. $\because{ }_{1}, 11 / 5,9 / 12$ ). Ved Lonsemaj tages en ny Dampskibsbygning i Brug. (II. ${ }^{28} / \mathrm{\theta}$ ). Assens-Aarasundfargens Bruttoindtagter var 164,(0)0 Kr. (H. Amtst. ${ }^{16}{ }_{5}$ ).

Telefonforbindelserne forbedredes ved Indforelse af billig Taksttelefon i Byerne. (H. $\left.{ }^{2} / \theta\right)$.

\section{Kommunale Forhold.}

I $1926^{\circ}$ kunde mange Kommuner nedsatte deres Skat teudskrivning ret betydeligt: Aabenraa med 135, (1) Kr. (II. ${ }^{6} / 1$ ), Haderslev, der $25-26$ har $66 \% 9$ Skatteydere ( $: 11$ Fremgang) med 16,9 Mill. skattepligtig Indkomst (H. ${ }^{13 / 3} / 3$, nedsætter Skatteprocenten fra 12,2 til $8,7\left(\right.$ H. ${ }^{12} / 4$, H. Amtst. ${ }^{1}{ }_{3}$ ) og sit Budget med over $3 / 4$ Mill. (H. ${ }^{27} / 2$ ). I Sonderborg neswttes Procenten fra 9,3 til 8,7, i Aabenraa blev den $8,5\left(\right.$ H. $\left.{ }^{8 / 4}\right)$ og i Tonder $8 \%$. (H. $\left.{ }^{12} / 4\right)$. Haderslev fik et Overskud paa $39 \pi, 000$, der overfartes til et Reserveog Skattereguleringsfond. (H. $\left.{ }^{29}, 10\right)$. Ogsaa Amterne kunde spare en Del. Haderslev Amtsskatter gik ned med $10 \%$. (H. ${ }^{11} / \mathrm{s},{ }^{30} / 11$ ). Tunder med 109,000$) \mathrm{Kr}$. (Av. ${ }^{19} / 12,{ }^{27} / 3$ ) Aabenraa med 118,000. (H. $\left.{ }^{20} / 12\right)$. De sonderjydske Byer synes 
for Resten ikke (som paastaaet) at forvaltes dyrere end normalt. (H. ${ }^{28} / 1,{ }^{20} / 2$ ).

I Sønderborg rejste Valsemøllen Erstatningskrav mod Havnen. (H. ${ }^{18} / 1$ ). I Tønder trængte Elektricitetsværket til en Udvidelse til 150,000 Kr. (Av. ${ }^{21} / 2$ ). Byraadet udsatte den dog. (Av. ${ }^{18} / 4$ ). Rødding kanaliseres (H. ${ }^{22} / 5$ ), og 130 Lejligheder faar Tilslutning til det nye Vandværk. (H. ${ }^{28} / 5$ ). I Haderslev flyttes Torvehandelen til Gravene (H. Amtst. ${ }^{17} / 6$ ), der bygges en Bro og en Gymnastiksal som Nødhjælpsarbejder. (H. Amtst. $8 / 8$ ). Elektricitetsværket havde 25-26 40,91 \% Fremgang i Produktion, Gasværket 13,9. (H. Amtst. ${ }^{13} / 11$ ).

\section{Menighedslivet.}

Spørgsmaalet om Præstegaardenes Udstykn ing er endnu ikke ført til Ende. Husmandsforeningernes Kursus krævede den gennemført (H. $\left.{ }^{8} / 1\right)$, og Pastor Poulsen sagde ved samme Lejlighed, at han ikke troede; Sognene havde Retten til Præstegaardene. (H. 4/1) Sognenes økonomiske Forhold er for Resten ikke glimrende. Deres Krigslaan, ca. 1 Mill. Kr., udbetales dem med $25 \%$ i Løbet af 30 Aar. $\left(\right.$ H. ${ }^{10} / 2$ ). Enkelte Steder formindskes deres Indtægt betydeligt ved, at Tyskerne danner egne Menigheder og derved slipper for at betale Kirkeskat. I Vilstrup f. Eks. med 800 Kroner. (H. ${ }^{25} / \mathrm{s},{ }^{28} / 5$ ). G e n indvi et efter Istandsættelser blev Adsbøl, Løgumkloster og Gl. Haderslev Kirker. (H. $\left.{ }^{12} / 4,{ }^{12} / 7,{ }^{11} / 10\right)$. Gram Kirke overdrog Grev Brockenhuus-Schack til Sognet. (H. ${ }^{17} / 7$ ). Naar tyske Blade paastod, at der manglede $10,000 \mathrm{Kr}$. i S. Vilstrup Kirkekasse (H. ${ }^{19} / 6$ ), var det ikke sandt. (H. ${ }^{23} / \mathrm{e}$ ). I Sønderborg indsattes en ny dansk Andenpræst. (H. ${ }^{10 / 4}$ ). Det aarlige kirkelige Møde i Vedsted samlede 1100. (H. $5 / 7$ ). Rødding Frimenighedskirkes Gæld er nu nede paa 25,000 Kr., Menighedens Regnskab balancerer med 14,195 Kr. (H. 1/2). Tyske Blade bringer Splid ind $i$ den katolske Menighed, der er sammensat af ca. 20 forskellige Nationaliteter. (H. ${ }^{15} / \mathbf{s}$ ).

\section{Oplysning.}

Af Skoler var der i Haderslev Amt 106 med 313 Klasser og 8134 Børn; der er 2 Skoler, ialt 11 Klasser, med 
433 Børn tysksprogede. Der er 100 Efter- og Aftenskoler med 679 Elever. (H. 1/3, 18/9). I Aabenraa Amt er der 66 dansk- og 6 tysksprogede Afdelinger med 4242 og 382 Børn. Der er desuden 6 tyske Privatskoler. (H. 15/4). I Tønder Amt var der 100 offentlige Skoler, deraf 19 tysksprogede og desuden 3 tyske Privatskoler. (H. ${ }^{28} / 4$ ). 3882 Børn undervistes paa Dansk, 983 paa Tysk, deraf 80 privat. (Ber. om Skolevæesenet i Tønder Amt 1926. (H. ${ }^{16} / 6$ ). Studentereksamen tog i Haderslev 27, Tønder 5, Sønderborg 21, Aabenraa 5, Realeksamen henhv. 28, 29, 29, 22. (Statsskolernes Beretninger). Ny Skoler indviedes i Kidskelund (Av. ${ }^{1 / 8}$ ), og Hertug Hansskolen i Haderslev udvidedes. (H. 8/12). Rens E f ers k o le havde Vinteren 25-26 27 Elever, om Sommeren 16, der ventedes til Vinteren 26-27 35, deraf 7 fra Rens. (Av. ${ }^{24} / 0$ ). Danebod $\mathrm{H} ø \mathrm{j} \mathrm{s} \mathrm{k} \mathrm{ole} \mathrm{havde} 60$ Sommerelever. (H. ${ }^{11} / 3$ ). H. Lund valgtes tll Forstander for Rødding ,Højskole. (H. ${ }^{20} / 4,8 / 11$ ). Georg Christensen bliver Forstander for Haderslev Sem in a ri um. (H. Amtst. ${ }^{2} / 1$ )

Højskoleh jemmet i Haderslev har Aktiver for $85,000 \mathrm{Kr}$., Passiver for 59,000. (H. ${ }^{26} / 2$ ). Forsamlingshuset paa Rømø fik 1800 Kroner af det opløste Landeværns Plantningsselskab. (H. ${ }^{23} / 6$ ).

Der indsamledes 45,000 Bøg e $\mathrm{r}$ til Sønderjylland. (H. 2/2). Biblioteket i Tønder udlaante 1925-26 22,093 Bind og havde 6769 Læsestuebesøg. (Av. $9 / 5$ ). Begge Dele er mere end fordoblet siden Oprettelsen for 3 Aar siden. Biblioteket faar en ny Bygning. (Av. ${ }^{10} / 10,18 / 10$ ). Det i Sønderborg udlaante 53,000 (5000 Fremgang). (H. 18/5).

\section{Ret og Forvaltning.}

I Haderslev faldt der i Februar en Række Domme i den vidtforgrenede Sædelighedssag. (H. $\left.{ }^{12},{ }^{13}, 10 / 2\right)$. Hen paa Sommeren viste der sig at være foregaaet en lang Række Svindlerier i Forsikringssager, navnlig i Haderslev Amt. (H. ${ }^{23} / 7,{ }^{30} / 7,18 / 8,18 / 8,15 / 9,16 / 8$ ). Ogsaa et Par Sager, der rejstes mod Gaardejer Kylling i Frørup for Fornærmelser, vakte en Del Opsigt. (H. $\left.{ }^{22} / 7,1 / 10,6 / 11\right)$. Ophævelsen af Søndre Landsret var i Januar til Forhandling i Folketinget. (H. $\left.{ }^{30} / 1,1 / 2\right)$. Den fandt stærk Modstand her nede. (H. $/ 2$ ). Amtsassessoŕembederne ophævedes.

\section{Personlige Forhold.}

Af Dødsfald i 1926 skal nævnes Fisker Peter Jensen i Egernsund, (H. 5/1), Margrethe Johannsen i Flens- 
borg, (H. ${ }^{1 / 2}$, Av. $2 / 2$, Falle Lildholdt i Lajtkirkeby, (H. ${ }^{8 / 2}$ ), Pastor Rolfs i IIcjer, (H. $\left.{ }^{16} / 3\right)$, F. C. Hansen i Løjtertoft, (II. ${ }^{17} / 3$ ), Degn P. E. Jensen i Mogeltønder, (H. ${ }^{18} / 3$, Av. ${ }^{18} / 3$ ), Dr. Petersen i (Gram, (H. ${ }^{31} / 3$ ), A. Lebeck, (H. $\left.{ }^{26} / 4\right)$, Driftshestyrer Dehlholm i Haderslev, (H. $\left.{ }^{10}{ }_{5}\right)$, Lektor Ascanius i Haderslev, (H. $\left.{ }^{4} / 8\right)$, Ida Petersen, Haderslev, (H. $\left.{ }^{24} / 11\right)$, Chr. Hansen, Tinggaard, (H. 10/12), Fru Reimers, Sønderborg, (H. ${ }_{23}{ }_{12}$ ), Petræus Lassen, Hjemsted, $\left(\right.$ H. $\left.{ }^{20} / 12\right)$.

Prof. Jac. Nielsen, der er fodt paa Als, valgtes til Medlem af Videnskabernes Selskab, (H. $\left.{ }^{12}{ }_{4}\right)$, Mindesmærke rejstes over P. Indresen $i$ tullerup $\left(H .{ }^{7 / 6}\right.$ ) og P. Reimers (H. ${ }^{25}{ }^{11}$ ). P. Skovroy hadredes paa sin 75 Aarsdag. (II. $\because 6)$.

\section{Andre Sager.}

Der skete 1920-25 Brandskader i Sonderjylland for 14 Mill. (H. ${ }^{15} / 2$ ). 1856 havde Aabenraa 80, Haderslev 66 og Strnderborg 61 Skibe. (H. $5 / 5$ ). Overfredningsnævnet bestemmer, at Reklameskilte ved Vejen paa Dybbol skal fjernes mindst $1(0) \mathrm{m}$ fra Vejen. (H. ${ }^{23} / 7$ ). Paa Roms indførtes frivillig treaarig Fredning for Edderfugle og Gravaיnder. (Av. $7 / 2$ ). Glasaalene udeblev fra Hojer Sluse, vistnok paa Grund af Damningen til Sild. (Av. $\left.{ }^{6} / 10\right)$. I Aabenraa aabnedes et Amtsmuseum. (H. ${ }^{3 / 6} / 6$. Et Grandebrev fra Agerskov 15): fremdrages. (H. ${ }^{15} / 12$ ). 